\title{
The Visibility of Ukrainian Economists 1969-2005
}

Tom Coupe (Kyiv School of Economics and

Kyiv Economics Institute) 


\title{
The Visibility of Ukrainian Economists 1969-2005
}

\author{
Tom Coupé \\ Kyiv School of Economics and Kyiv Economics Institute
}

\begin{abstract}
:
This article studies the visibility of Ukrainian economists. It shows that the number of Ukrainians trained at Western universities is increasing fast and that these economists now start publishing in international journals. At the same time, Ukrainian economists residing and educated in Ukraine still rarely publish in international economics journals. An explanation for both findings is offered.
\end{abstract}

JEL: A100

Keywords: ranking, Ukraine, economists 


\section{Introduction}

Mirucki (1999) studied the contribution of Ukrainian economists to the international economics literature based on the ECONLIT database for the period 1969-1994. He identified Ukrainian economists by using books on the history of economic thought in Ukraine, by looking at the editorial board of a Ukrainian economics journal and by looking at the names of speakers at the congress of the Ukrainian economic association. In this article, I identify how the visibility of Ukrainian economists, as defined by Mirucki, has developed in the period 1995-2005. I also look at a second indicator of visibility, the number of Ukrainians with PHD from Western schools.

One of the most striking findings of Mirucki was the almost complete absence of Ukrainian economists in international refereed journals. He found 14 Ukrainian economists who were based in Ukraine and 10 'Diaspora' economists based abroad. The 14 'local' economists had published in only 3 different economics journals, none of which can be considered as a top economics journal (Problems of Economics, European Review of Agricultural Economics, International Regional Science Review). The 10 'Diaspora' economists had been more active publishing, together contributing to 39 different articles, some of which were published in journals like Atlantic Economic Review, Journal of Comparative Economics and Journal of Development Economics.

This modest contribution of Ukrainian economists to the international literature was not that surprising given the isolation of the Soviet Union. After the fall of the Soviet Union, however, several initiatives were taken to stimulate the development of modern economics in Ukraine. In this article, we show how these initiatives have changed the visibility of Ukrainian economists. We find that these initiatives have lead to a generation of Ukrainian economists who have studied in the West and start publishing in international journals. At the same time, Ukrainian economists that have been educated and work in Ukraine still do not publish in international journals. We offer an explanation for this based on the incentive system in Ukrainian academia.

\section{The visibility of Ukrainian economists}

To look at the publishing performance of Ukrainian economists, one first needs to identify the Ukrainian economists. To makes a list of Ukrainian economists, we downloaded from Econlit all journal articles that have authors affiliated to institutions located in Ukraine or that have the word Ukraine in the title or abstract ${ }^{1}$. This search resulted in a total of 229 records. We then distilled a list of Ukrainian economists from the list of authors of these 229 articles. We then checked in Econlit for other publications of these economists. In addition we searched for the names of Ukrainian economists who received a PHD from Western universities. I also looked through the list of economics alumni of the Muskie/Freedom Support Act Program and looked at the economists that are member of the Ukrainian Academy of Sciences ${ }^{2}$. Finally, the authors included in Mirucki (1999) were added. Note however that in contrast to the latter article I will focus on articles and exclude books, books chapters and book reviews.

\footnotetext{
${ }^{1}$ The exact search term we used was: ((ukraine in ab) or (ukraine in ti) or (ukraine in af) or (ukrainian in af) or (Kyiv in af) or (kiev in af))and (journal article in dt)

${ }^{2}$ The list of alumni is confidential but I found a list of fellows for 1992-1996. Very few names of this list were found to publish so not having the list for later years is unlikely to have a big impact. The local IREX office sent a mail around to its alumni asking for people studying for phd to contact me - I only got one reply.
} 
A total of 86 Ukrainians published in journals that are indexed in Econlit in the period 1969$2005^{3}$. They together contributed to 121 articles. If we attribute coauthorship proportionally, 92 papers have been written by these Ukrainian authors. Note in this list of 86 we do not only have academics, we also have politicians like Prime Minister Yekhanurov and President Yuchenko. Moreover, remember that our initial search in Econlit gave us 229 publications related to Ukraine - since these 121 articles include several articles that are on subjects unrelated to Ukraine, most of the international research on Ukraine has been done by foreign researchers.

A first look at table 1 shows that very few of the Ukrainians are frequent publishers. Lilia and Serguei Maliar are, with 11 publications in the Econlit database, the biggest Ukrainian contributors - note that Coupé (2003) finds that to be in the top 500 of economists for the period 1990-2000 you had to publish more than 17 articles. The younger economists in the list still can reach such a level, the Maliars' first publication was only in 2000, but Table 1 indicates that the older economists in the list do not publish regularly internationally Lukinov, who shares the $4^{\text {th }}$ place in terms of number of publications, for example, has his first publication in 1969 and his fourth in 1996.

[insert table 1 here]

Besides the quantity of publications, one also needs to look at the quality. Compared to the period Mirucki looked at, we now have several Ukrainians who published in top journals Skiba and Konstantinova have publications in the Journal of Political Economy, Love in the Journal of Finance. However, note that Vladimir Korobov (Kherson Pedagogical Institute) already published in the American Economic Review in 1991. Table 1 uses 2 different quality weighting methods - a first method uses the recent weighting scheme of Kalaitzidakis et al (2003), the second is based on Bauwens (1999). The first journal ranking method only gives weights to the core economics journals in Econlit and excludes finance journals, statistical journals or business journals ${ }^{4}$. The ranking of journals is based on weighted citations - that is a journal ranks high if it is cited by other journals that are highly cited. The Bauwens method gives a score ranging from 1 to 5 to all journals included in Econlit, with the score based on the total number of citations of the journal and the impact factor. Note that in addition to weighting for quality, both methods also weight for the number of coauthors - the value of a coauthored paper is divided proportionally over the coauthors.

Weighting matters and the specificity of each ranking methodology has its influence. Inessa Love is $4^{\text {th }}$ on the Bauwens ranking but drops out of the top 10 if we use the Kalaitzidakis et al methodology which does not value publications in the Journal of Finance. Skiba and Konstantinova just have one coauthored paper but because this paper is published in a top journal it is sufficient to become $4^{\text {th }}$ in the ranking based on the Kalaitzidakis et al ranking. One noticeable thing is that the Kalaitzidakis et al ranking favors younger authors - they published less but published in journals that are more core economics journals.

We clearly can see that things are improving from the evolution of the number of publications over time - while before the number of publications per year was no more than 6 (with the

\footnotetext{
${ }^{3}$ In addition, I found 15 economists who could be considered Diaspora economists - economists with a Ukrainian background but not necessarily nationality. I tried to determine nationality based on CV or info on the internet.

${ }^{4}$ Their ranking also correct for differences in page sizes.
} 
exception of 2000), the number of publications with input of Ukrainian economists was 18 in 2003 and even 34 in 2004. Also the average quality per article increased (see table 2).

[Insert table 2 here]

The more recent publications are typically written by Ukrainian economists with a Western Phd degree, and not by economists with a Ukrainian Candidate or Doctoral Degree. That things are improving is hence mainly due to the fact that the number of Ukrainians with PHDs is increasing - at least 35 Ukrainians graduated with a PHD from a Western University since 1995. The following list gives their background (explained below), their names, the universities where they graduated, the year of graduation and the current affiliation of these 35 economists.

\section{$\underline{\text { EERC alumni }}$}

Bilotkach, Volodymyr, Arizona (2005), U California-Irvine

Bodnaruk, Andriy., Stockholm (2005), Maastricht.

Holod, Dmytro., Kentucky (2005), SUNY-Stony Brook.

Ivaschenko, Iryna, Stockholm, (2003), IMF

Kitsul, Yuri, North Carolina, (2005), Georgia State.

Korenok, Oleh, Rutgers (2005),. Virginia Commonwealth U

Luhovsky, Volodymyr , Purdue (2004) U Memphis

Mylovanov, Timofey, Wisconsin (2004) U Bonn

Nizalova, Olena, Michigan State (2005), EERC-EROC \& KEI

Prokopovich, Pavlo, Michigan (2005), EERC-EROC \& KEI

Talavera, Olexandr, European University Viadrina (2005), DIW

Zapechelnyuk, Andriy. SUNY-Stony Brook (2005), Hebrew University, Jerusalem

\section{MUSKIE/FSA alumni (or similar)}

Grinchak, Oksana, U Chicago (2001), Credit Suisse First Boston

Konstantinova-Vernon, Victoria U Texas (2004), U Texas

Kotlyarova, Yulia, McGill U (2005), Dalhousie U

Kryvtsov, Oleksiy, U Minnesota (2004), Bank of Canada

Love, Inessa Columbia U (2001), World Bank

Moshkin, Nikolay, Yale (2001), Cornerstone Research

Sidorenko, Alexandra, Australian National U (XXXX), Australian National U

Skiba, A , Purdue (2004), U Kansas

Vlasenko, Polina, U Maryland (2004), Manchester College, Indiana

Zelenyuk, Valentin, Oregon State U (2002), EERC-EROC \& KEI

\section{Other}

Blavatskyy, Pavlo, CERGE-EI (2004), U Zurich

Bodnar, Taras Europa-Universität Viadrina (2004), Europa-Universität Viadrina, Frankfurt

Golosnoy, Vasyl, Europa-Universität Viadrina (2004), University of Kiel

Havrylchyk, Olena, Europa-Universität Viadrina (2005), CEPII France 
Kozhan, Roman, Europa-Universität Viadrina (2005), Warwick Business School

Maliar, Lilia, U Pompeu Fabra (1999), U Alicante

Maliar, Serguei, U Pompeu Fabra (1999), U Alicante

Okhrin, Yarema, Europa-Universität Viadrina (2004), Europa-Universität Viadrina

Radchenko, Stanislav, Rutgers (2002), U North Carolina, Chapel Hill

Shestalova, Victoria, Tilburg (2002), Central Planning Bureau, Netherlands

Tchernis, Rusty, Brown (2002), Indiana U

Vereshchagina, Galina (2004), U Iowa

Voronkova, Svitlana Europa-Universität Viadrina (2004), University of Dublin

This list shows that most Ukrainians who went abroad to do a PHD remain abroad after graduation, illustrating the brain drain effect. Only 3 of them returned to work as academics in Ukraine. Several of the remaining 32, however, keep ties to Ukraine through participation in conferences, research on Ukraine or by teaching short courses in Ukraine. Noteworthy is further the low percentage of PHDs who work for the private sector after graduation and the fact that Ukrainians who went to Europe to study also tend to work in Europe afterwards, and similar, Ukrainians who went to the US to study also remain in the US afterwards.

If we look at the affiliations of the Ukrainian researchers that published (Table A1 in the Appendix), we can see that there is a lot of diversity in affiliation - it is clear that there are no institutions that gather several Ukrainian economists who publish in international journals. Most publications originate by Ukrainian economists with a PHD but working abroad, few by those working in Ukraine . In the next section, we will explain both why the number of Ukrainian PHDs has started to increase so substantially and why locally trained economists rarely publish in international journals.

\section{Capacity building in Economics in Ukraine.}

The increase of the number of Ukrainian economists with a Western degree is to a great extent due to a number of capacity building programs that have been established by international donors after the fall of the Soviet Union.

Alexeev et al (1992) offer a good description of the state of economics a the beginning of the 90ies. Soviet-trained economists, they indicate, were very different from the Western-trained economists - they either specialized in 'political economy', meaning Marxist-Leninist style of economics or 'mathematical economics', which focused on mathematics rather than economics. Alexeev et al. concluded that 'while reasonable people can differ over exactly what economic curriculum should be established in the former Soviet Union, surely it should be a significant departure from either the political or mathematical approaches from the past'.

In response to this need for training and retraining, several initiatives supported by Western foundations and governments were taken. These initiatives ranged from sending people to the West to study economics, and retraining economics teachers to the establishment of a western-style MA program.

First, in 1992 the Muskie fellowship program started sending students from the CIS to the US for a one to two year education, at the MA level, in economics and other social sciences. The idea behind this program was to expose these students 'to the U.S. market economy and to democracy in practice' (University of Iowa Social Science Institute, 2002) in this way giving 
them skills and ideas that could not be provided by communist education. While the Muskie fellowship have a 'home'-requirement so that beneficiaries of the fellowship have to return to their home countries after their studies, many students decided to continue and obtain a PHD before leaving the US as witnessed by the list of PHDs above.

From the list of PHDs, one can also see a second source of supply - the EERC MA program. In 1994, the Economics Education and Research consortium was created to build capacity in economics research and education in the former Soviet Union. This was done through a CIS wide grant competition which provides research grants for modern economics research and through an MA program. At the MA program in Kyiv, which opened in 1996, students are taught modern economics during two years in English by professors who have PHDs from Western universities. About 300 students have graduated from this program so far, and more than one third of these have left Ukraine to obtain a PHD in the West.

While capacity building initiatives can explain the increasing number of PHDs, they cannot explain why the locally trained economists do not succeed in publishing more regularly in international journals. The explanation for this absence lies in the incentive system in Ukrainian academia..

\section{Incentives in Ukrainian academia.}

Kerr (1975)'s seminal article 'On the Folly of Rewarding A, while hoping for B' has many illustrations of how incentive systems often lead to unwanted outcomes. Among the many examples he uses, he also covers some education related examples. He describes how universities want professors to deliver high quality lectures but at the same time, mainly reward research performance. And how society want universities to transfer knowledge, but since such transfer is measured by grades, students try to obtain good grades rather than to obtain knowledge.

The Ukrainian academic world offers some more interesting examples, especially the system that is used to confer scientific degrees. To get such a degree, one needs to do original research and publish in academic journals, one needs to participate in conferences and one needs to defend a Candidate or Doctoral thesis. These requirements are very similar to the requirements at good universities in Western Europe and North-America. Still, the implementation of these rules and the results differ quite substantially.

At good universities in Western Europe and North America, a doctoral thesis in economics typically consists of 3 articles that are 'publishable'. What is 'publishable' is left to a scientific committee of university professors, the thesis jury, which typically consists of some professors of the university that awards the degree and at least one member of another university system. Many thesis articles never get published - about half of all phd graduates never publish any article (Coupé, 2000). This is partially because some of these articles are not of publishable quality and partially because a big part of phds start working in the private sector (and hence do no longer care about academic publications) rather than academia. Phds who aim to stay in academia have a big incentive to publish their research in journals since this will determine the success or failure of their career.

In Ukraine, to obtain a 'candidate of science degree', one needs to publish 3 to 5 papers in journals recognized by the Central Attestation Committee. Hence, at first sight, this is a stricter rule since the articles need to be 'published' rather than being 'publishable'. However, 
the Central Attestation Committee's list only contains Ukrainian and Russian Language journals. Unfortunately, such local economics journals are of very poor quality, especially if compared to international journals.

Many countries have such local journals, journals that only receive submissions by the economists of the country - but almost everywhere such local journals are of low quality, compared to the international journals which receive submissions by economists from all over the world. The fact that these international journals are better is due to the higher level of competition there is to publish in such journals and due to the fact that 'peer-review' is used by these journals. That is, a paper submitted to such journal is read by 2 or 3 other economists, called referees, who are unknown to the author of the paper, and evaluate the quality of the paper. If the paper has sufficient potential, the referees will provide comments and criticisms to the author and the paper will be published only if the author takes such comments into account and improves the paper.

Ukrainian academic journals often are peer-reviewed only in theory and in name but not in practice. In Ukrainian academia, 'peer review' basically means that somebody has to write a note that the papers are ready for publication - but there is no need to send comments to the authors of the submitted papers, neither are the authors supposed to modify their papers. Taken together with the low level of papers typically sent to local journals, one should not be surprised that Ukrainian journals do not enter the international rankings of journals and are not taken seriously anywhere in Western Europe or Northern America.

At good universities in Western Europe and Northern America, the standard for being 'publishable' is the standard of international journals. The reason for this is that, in order to be taken serious as an academic and in order to make a career at a good university, you need to publish in international journals. In Ukraine, given the focus of the Central Attestation Committee on local publications for the Candidate degree, there is no need to do research and compete at the international level.

The incentives for publications in local journals do not end after receiving one's 'candidate of science degree'. Getting a Doctor of Science degree (a second degree, to some extent comparable to obtaining a full professorship in Western terminology) is also linked to the number of publications in local journals, approved by the Central Attestation Committee. Local work is also more important to get state recognition (diplomas of cabinet of ministers, state prizes, honorary diplomas etc): in the annual report of the National Academy of Sciences (NAS) $^{5}$, the economics section indicates which NAS economists have been rewarded with such recognition. None of the mentioned recipients publish regularly in international journals, most of them do not have any such publication.

Like in the academic community in Western Europe and Northern America, also in Ukrainian academia, originality is highly appreciated in a research paper. Originality, however, can be obtained in different ways. In Western Europe and Northern America, it is important to situate one's paper in the literature and clearly state how one's paper improves on the state of the literature. The approach to originality in Ukrainian academia is somewhat different - clearly situating one's article in the literature is dangerous since it shows a lot of work in the area has been done already and would lead to being criticized for a lack of originality. As a

\footnotetext{
${ }^{5}$ http://www.nas.gov.ua/En/main.html
} 
consequence, not referring to original sources, i.e. plagiarism, is widespread and widely accepted as normal practice.

Besides doing research, academics typically also present their research at seminars and conferences. Presenting research has several beneficial aspects - it creates deadlines for oneself and it allows one to receive comments on a paper which can be used to improve the paper. In Ukraine, presenting one's work at a number of conferences is also a requirement for getting a degree. What is important, however, is that a paper got accepted at a conference, appears in the conference agenda and in the conference proceedings. If the conference proceedings and agenda are printed before the actual conference takes place, then one does not need to go to the conference anymore. At good universities in Western Europe and Northern America, conference participation is not counted but typically recommended as a networking tool to meet researchers with similar interest.

To get a degree, an economist needs to defend his research for a jury. At good universities in Northern America and Western Europe, a fairly 'impartial' jury provides 'peer review', it reads the thesis and provides comments that need to be incorporated by the defendant. In Ukraine, however, peer review is often done by the defendant him/herself, that is, the defendant has to write sets of comments for the jury members. This practice is very similar to what happens to letters of recommendation in Ukraine - most often letters of recommendation are written by the person who needs them and then provides them for signing to the people who are asked to be referee.

The above description provides a clear explanation why Ukrainian-trained researchers do not succeed and are not interested in publishing in international journals. The Ukrainian incentive system rewards local publications and requirements for publication in local journals are very different from the requirements to publish in international journals.

\section{Conclusions}

Even 15 years after the end of the Soviet Union, Ukraine's contribution to the modern economics literature remains very limited. Still, there are more and more Ukrainians with PHDs from Western schools, and more and more Ukrainians are publishing in good economics journals. This is mainly the result from a number of capacity building initiatives that started after the fall of the Soviet Union which stimulated Ukrainians to obtain degrees abroad. Ukrainian academics trained and based in Ukraine, however, have still no incentive to try to publish internationally given an incentive system in Ukrainian academia which is focused completely on local publications. 


\section{References}

Alexeev, Micheal, Clifford Gaddy and Jim Leitzel (1992), 'Economics in the Former Soviet Union', Journal of Economic Perspectives, vol. 6(2), p. 137 -148

Bauwens, Luc (1999), 'Economics Research in Belgium', unpublished manuscript available at http://www.core.ucl.ac.be/econometrics/Bauwens/rankings/rankings.htm

Coupé, Tom (2000), "Basic Statistics for Economists", mimeo available at http://student.ulb.ac.be/ tcoupe/

Coupé, Tom (2003) 'Revealed Performances: Worldwide Rankings of Economists and Economics Departments, 1990-2000', Journal of the European Economic Association, vol. 1(6), p 1309-1345

Kalaitzidakis, Pantelis, Thanasis Stengos and Theofanis P. Mamuneas (2003), 'Rankings of Academic Journals and Institutions in Economics', Journal of the European Economic Association, vol. 1(6), p. 1346-1366

Kerr, Steven (1975), 'The Folly of Rewarding A, While Hoping for B”, The Academy of Management Journal, vol 18(4), p. 769-783.

Mirucki, Jean (1999), 'A Visibility Analysis of the Scientific Production of Ukrainian Economists: 1969-94’, Journal of Socio-Economics, vol. 28(2), p. 185-196

University of Iowa Social Science Institute (2002), 'Executive Summary of the Edmund S. Muskie/ Freedom Support Act Graduate Fellowship Program’, available at http://exchanges.state.gov/education/evaluations/execsummaries/Muskie-FSAGrad.pdf 
Tables

Table 1 - Ranking of Ukrainian Economists

\begin{tabular}{|c|c|c|c|c|}
\hline Name & coauthorweighted & KLM & Bauwens & $\begin{array}{l}\text { nr of } \\
\text { articles }\end{array}$ \\
\hline Maliar,-Lilia & 5,5 & 40,9 & 12,0 & 11 \\
\hline Maliar,-Serguei & 5,5 & 40,9 & 12,0 & 11 \\
\hline Love,-Inessa & 2,8 & 1,8 & 10,8 & 5 \\
\hline Lukinov,-Ivan-I & 3,5 & 0,2 & 4,0 & $\overline{4}$ \\
\hline Petryk,-Oleksandr-Ivanovych & 4,0 & 0,0 & 4,0 & 4 \\
\hline Zelenyuk,-Valentin & 1,7 & 0,0 & 1,7 & 4 \\
\hline Shestalova, Victoria & 2,5 & 1,8 & 3,5 & 3 \\
\hline Pivovarsky,-Alexander & 2,3 & 0,0 & 2,3 & 3 \\
\hline Ivaschenko,-Iryna-V & 2,0 & 0,0 & 2,0 & 3 \\
\hline Kukush,-Alexander & 1,2 & 0,0 & 1,2 & 3 \\
\hline Moshkin,-Nickolay-V & 1,5 & 0,4 & 3,5 & 2 \\
\hline Korobov,-Vladimir & 0,7 & 33,3 & 3,0 & 2 \\
\hline Bilotkach,-Volodymyr & 2,0 & 0,8 & 3,0 & 2 \\
\hline Popov,-Mikhail-I & 1,5 & 0,0 & 3,0 & 2 \\
\hline Radchenko,-Stanislav-I & 1,0 & 9,4 & 2,0 & 2 \\
\hline Butenko,-A & 2,0 & 0,0 & 2,0 & 2 \\
\hline Pynzenyk,-Viktor & 2,0 & 0,0 & 2,0 & 2 \\
\hline Rumiantsev,-A & 2,0 & 0,0 & 2,0 & 2 \\
\hline Yastremsky,-Oleksander & 2,0 & 0,0 & 2,0 & 2 \\
\hline Khmelko,-Valeri & 0,7 & 0,1 & 1,3 & 2 \\
\hline Akimova,-Iryna & 1,0 & 0,0 & 1,0 & 2 \\
\hline Mortikov,-Vitalii-Vladimirovich & 1,0 & 0,0 & 1,0 & 2 \\
\hline Verstyuk,-Sergiy & 1,0 & 5,0 & 3,0 & 1 \\
\hline Bilan, Olena & 1,0 & 3,4 & 3,0 & 1 \\
\hline Dmytro Boyarchuk & 1,0 & 3,4 & 3,0 & 1 \\
\hline Skiba,-Alexandre & 0,5 & 32,6 & 2,5 & 1 \\
\hline Vernon,-Victoria Konstantinova & 0,5 & 32,6 & 2,5 & 1 \\
\hline Voitovich,-Sergei-A & 1,0 & 0,1 & 2,0 & 1 \\
\hline Chumachenko,-Nikolai-G & 1,0 & 0,0 & 2,0 & 1 \\
\hline Dolishny,-M-I & 1,0 & 0,0 & 2,0 & 1 \\
\hline Holod,-Dmytro & 0,5 & 9,4 & 1,5 & 1 \\
\hline Gorodnichenko,-Yuriy & 0,5 & 1,7 & 1,5 & 1 \\
\hline Cabelkova,-Inna & 0,5 & 1,0 & 1,5 & 1 \\
\hline Sushko,-Irina & 0,3 & 2,3 & 1,0 & 1 \\
\hline Malysh,-Nadia & 1,0 & 0,1 & 1,0 & 1 \\
\hline Teriokhin,-Serhyi & 1,0 & 0,1 & 1,0 & 1 \\
\hline Yekhanurov,-Yuri-I & 1,0 & 0,1 & 1,0 & 1 \\
\hline Pugachov,-Mykola & 0,5 & 0,0 & 1,0 & 1 \\
\hline Boyko,-Natalka & 1,0 & 0,0 & 1,0 & 1 \\
\hline Burakovsky,-Igor-V & 1,0 & 0,0 & 1,0 & 1 \\
\hline Doroguntsov,-Sergey-I & 0,5 & 0,0 & 1,0 & 1 \\
\hline Khomra a & 1,0 & 0,0 & 1,0 & 1 \\
\hline Komarov,-Kostyantyn & 1,0 & 0,0 & 1,0 & 1 \\
\hline Kostyuk,-Alexander & 1,0 & 0,0 & 1,0 & 1 \\
\hline Lanoviy,-Volodymyr & 1,0 & 0,0 & 1,0 & 1 \\
\hline
\end{tabular}




\begin{tabular}{|c|c|c|c|c|}
\hline Lukyanenko,-Iryna & 1,0 & 0,0 & 1,0 & 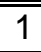 \\
\hline Mamutov,-V-K & 1,0 & 0,0 & 1,0 & 1 \\
\hline Onishchenko,-Vladimir-F & 0,5 & 0,0 & 1,0 & 1 \\
\hline Rodionov,-Aleksandr & 1,0 & 0,0 & 1,0 & 1 \\
\hline shepotko I & 1,0 & 0,0 & 1,0 & 1 \\
\hline Shevchuk,-Victor & 1,0 & 0,0 & 1,0 & 1 \\
\hline Shpek,-Roman-V & 1,0 & 0,0 & 1,0 & 1 \\
\hline Sidorenko,-Tatiana & 1,0 & 0,0 & 1,0 & 1 \\
\hline Slukhai,-Sergii & 1,0 & 0,0 & 1,0 & 1 \\
\hline Slutskii,-Evgenii-Evgenievich & 1,0 & 0,0 & 1,0 & 1 \\
\hline Stotyka,-Y & 1,0 & 0,0 & 1,0 & 1 \\
\hline Yushchenko,-Viktor & 1,0 & 0,0 & 1,0 & 1 \\
\hline Havrylchyk,-Olena & 1,0 & 0,0 & 1,0 & 1 \\
\hline Voronkova,-Svitlana & 1,0 & 0,0 & 1,0 & 1 \\
\hline Talavera,-Oleksandr & 0,5 & 0,0 & 0,5 & 1 \\
\hline Sidenko,-Volodimir-R & 0,5 & 0,0 & 0,5 & 1 \\
\hline Andreyeva,-Tatiana & 0,5 & 0,0 & 0,5 & 1 \\
\hline Azarenkova,-Ganna & 0,5 & 0,0 & 0,5 & 1 \\
\hline Chuyko,-Helen & 0,5 & 0,0 & 0,5 & 1 \\
\hline Kozmenko,-Sergey & 0,5 & 0,0 & 0,5 & 1 \\
\hline Mertens,-Alexander & 0,5 & 0,0 & 0,5 & 1 \\
\hline Popovkin,-Valerii & 0,5 & 0,0 & 0,5 & 1 \\
\hline Pyrozhkov,-Serhii & 0,5 & 0,0 & 0,5 & 1 \\
\hline Sidorenko,-Alexandra & 0,5 & 0,0 & 0,5 & 1 \\
\hline Starostyna,-Alla & 0,5 & 0,0 & 0,5 & 1 \\
\hline Tchernis,-Rusty & 0,5 & 0,0 & 0,5 & 1 \\
\hline Vasyurenko,-Oleg & 0,5 & 0,0 & 0,5 & 1 \\
\hline Zorya,-Sergiy & 0,5 & 0,0 & 0,5 & 1 \\
\hline Dzis,-G & 0,3 & 0,0 & 0,3 & 1 \\
\hline Kryvtsov,-Oleksiy & 0,3 & 0,0 & 0,3 & 1 \\
\hline Kupets,-Olga & 0,3 & 0,0 & 0,3 & 1 \\
\hline Litvak,-Irina & 0,3 & 0,0 & 0,3 & 1 \\
\hline lysenkov lu & 0,3 & 0,0 & 0,3 & 1 \\
\hline Murova,-Olga-I & 0,3 & 0,0 & 0,3 & 1 \\
\hline Onyshchenko,-J-V & 0,3 & 0,0 & 0,3 & 1 \\
\hline Plakhotnik,-V-N & 0,3 & 0,0 & 0,3 & 1 \\
\hline Rymaruk A & 0,3 & 0,0 & 0,3 & 1 \\
\hline Stoyan,-Yurij-Y & 0,3 & 0,0 & 0,3 & 1 \\
\hline Tratch,-Irina & 0,3 & 0,0 & 0,3 & 1 \\
\hline Ustenko,-Oleg & 0,3 & 0,0 & 0,3 & 1 \\
\hline Yaryshkina,-L-A & 0,3 & 0,0 & 0,3 & 1 \\
\hline
\end{tabular}

Table 2 - the evolution of the average quality of articles of Ukrainian authors.

\begin{tabular}{||l|l|l||}
\hline \hline & $\begin{array}{l}\text { average KLM score (min 0, } \\
\max 100)\end{array}$ & $\begin{array}{l}\text { average Bauwens score (min } \\
1, \max 5)\end{array}$ \\
\hline til 1990 & 0,01 & 1,20 \\
\hline $1991-2000$ & 2,52 & 1,37 \\
\hline $2001-2005$ & 4,04 & 1,79 \\
\hline
\end{tabular}

KLM is based on Kalaitzidakis et al (2003) 


\section{Appendix}

Table A1 - affiliations

\begin{tabular}{|c|c|}
\hline Name & Affiliation \\
\hline Maliar,-Lilia & Alicante and EERC-EROC \\
\hline Maliar,-Serguei & Alicante and EERC-EROC \\
\hline Segal,-Ilya & Stanford \\
\hline Love,-Inessa & world bank \\
\hline Lukinov,-Ivan-I & Ukrainian Academy of Sciences \\
\hline Petryk,-Oleksandr-Ivanovych & National Bank of Ukraine \\
\hline Zelenyuk,-Valentin & EERC and $\mathrm{KEI}$ \\
\hline Shestalova, Victoria & Tilburg \\
\hline Pivovarsky,-Alexander & IMF \\
\hline Ivaschenko,-Iryna-V & IMF \\
\hline Kukush,-Alexander & Kiev National Taras Shevchenko U \\
\hline Moshkin,-Nickolay-V & Cornerstone Research \\
\hline Korobov,-Vladimir & Kherson State Technical University \\
\hline Bilotkach,-Volodymyr & U CA Irvine \\
\hline Popov,-Mikhail-I & Donetsk State Technical \\
\hline Radchenko,-Stanislav-I & U NC, Chapel Hill \\
\hline \multicolumn{2}{|l|}{ Butenko,-A } \\
\hline Pynzenyk,-Viktor & Minister \\
\hline \multicolumn{2}{|l|}{ Rumiantsev,-A } \\
\hline Yastremsky,-Oleksander & International Christian University \\
\hline Khmelko,-Valeri & NAUKMA \\
\hline Akimova,-Iryna & UNDP \\
\hline Mortikov,-Vitalii-Vladimirovich & Kiev U Trade \\
\hline Verstyuk,-Sergiy & IER, Kyiv \\
\hline Bilan, Olena & Bleyzer Foundation \\
\hline Dmytro Boyarchuk & CASE Ukraine \\
\hline Skiba,-Alexandre & Kansas \\
\hline Vernon,-Victoria Konstantinova & U Texas \\
\hline Voitovich,-Sergei-A & Grishenko and Partners \\
\hline Chumachenko,-Nikolai-G & Ukrainian Academy of Sciences \\
\hline Dolishny,-M-I & Ukrainian Academy of Sciences \\
\hline Holod,-Dmytro & Stony Brook \\
\hline Gorodnichenko,-Yuriy & U Michigan \\
\hline Cabelkova,-Inna & CERGE-El, Charles U \\
\hline Sushko,-Irina & Ukrainian Academy of Sciences \\
\hline \multicolumn{2}{|l|}{ Malysh,-Nadia } \\
\hline Teriokhin,-Serhyi & Rada \\
\hline Yekhanurov,-Yuri-I & Prime Minister \\
\hline Pugachov,-Mykola & Undp \\
\hline Boyko,-Natalka & $\begin{array}{l}\text { IEP, Paris and } \\
\text { Sciences Politiques }\end{array}$ \\
\hline Burakovsky,-Igor-V & IER, Kyiv and NAUKMA \\
\hline Doroguntsov,-Sergey-I & Ukrainian Academy of Sciences \\
\hline \multicolumn{2}{|l|}{ Khomra a } \\
\hline Komarov,-Kostyantyn & $\begin{array}{l}\text { Kharkov State Academy } \\
\text { of Municipal Economy }\end{array}$ \\
\hline
\end{tabular}




\begin{tabular}{|c|c|}
\hline Kostyuk,-Alexander & Ukrainian Academy of Banking,National Bank of Ukraine \\
\hline Lanoviy,--Volodymyr & advisor to President \\
\hline Lukyanenko,-Iryna & NAUKMA and EERC \\
\hline Mamutov,-V-K & Ukrainian Academy of Sciences \\
\hline \multicolumn{2}{|c|}{ Onishchenko,-Vladimir-F } \\
\hline Rodionov,-Aleksandr & East Ukranian National U \\
\hline \multicolumn{2}{|l|}{ shepotko I } \\
\hline Shevchuk,-Victor & Lviv Academy of Commerce \\
\hline Shpek,-Roman-V & Ambassador \\
\hline Sidorenko,-Tatiana & Australian national U \\
\hline Slukhai,-Sergii & National Kyiv Taras Shevchenko U \\
\hline \multicolumn{2}{|c|}{ Slutskii,-Evgenii-Evgenievich } \\
\hline Stotyka,-Y & John Hopkins (PHD student) \\
\hline Yushchenko,-Viktor & President \\
\hline Havrylchyk,-Olena & CEPII \\
\hline Voronkova,-Svitlana & Dublin \\
\hline Talavera,-Oleksandr & DIW \\
\hline Sidenko,-Volodimir-R & Razumkov centre \\
\hline Andreyeva,-Tatiana & Rand \\
\hline Azarenkova,-Ganna & $\begin{array}{l}\text { Kharkov Institute of Banking, Ukrainian Academy of } \\
\text { Banking }\end{array}$ \\
\hline Chuyko,-Helen & Ukrainian Academy of Banking, National Bank of Ukraine \\
\hline Kozmenko,-Sergey & business perspectives sumy \\
\hline Mertens,-Alexander & NAUKMA and Kyiv Taras Shevchenko U \\
\hline \multicolumn{2}{|l|}{ Popovkin,-Valerii } \\
\hline Pyrozhkov,-Serhii & Ukrainian Academy of Sciences \\
\hline Sidorenko,-Alexandra & Australian national U \\
\hline \multicolumn{2}{|l|}{ Starostyna,-Alla } \\
\hline Tchernis,-Rusty & Indiana \\
\hline Vasyurenko,-Oleg & $\begin{array}{l}\text { Kharkov Institute of Banking, Ukrainian Academy of } \\
\text { Banking }\end{array}$ \\
\hline Zorya,-Sergiy & Georg-August U Gottingen \\
\hline \multicolumn{2}{|l|}{ Dzis,-G } \\
\hline Kryvtsov,-Oleksiy & Bank of Canada \\
\hline Kupets,-Olga & EERC \\
\hline Litvak,-Irina & Kiev Regional Hospital \#1 \\
\hline \multicolumn{2}{|l|}{ lysenkov lu } \\
\hline Murova,-Olga-I & Texas Tech U \\
\hline Onyshchenko,-J-V & Dniepropetrovsk National U Railway Transport \\
\hline Plakhotnik,-V-N & Dniepropetrovsk National U Railway Transport \\
\hline \multicolumn{2}{|l|}{ Rymaruk A } \\
\hline \multicolumn{2}{|l|}{ Stoyan,-Yurij-Y } \\
\hline \multicolumn{2}{|l|}{ Tratch,-Irina } \\
\hline Ustenko,-Oleg & CASE Ukraine \\
\hline Yaryshkina,-L-A & Dniepropetrovsk National U Railway Transport \\
\hline
\end{tabular}

